Research Report No. 26/2010

\title{
Constitutionalizing the Right of Workers to Organize, Bargain and Strike: The Sight of One Shoulder Shrugging
}

Harry W. Arthurs

Osgoode Hall Law School of York University, harthurs@osgoode.yorku.ca

Follow this and additional works at: http://digitalcommons.osgoode.yorku.ca/clpe

\section{Recommended Citation}

Arthurs, Harry W., "Constitutionalizing the Right of Workers to Organize, Bargain and Strike: The Sight of One Shoulder Shrugging"

(2010). Comparative Research in Law \& Political Economy. Research Paper No. 26/2010.

http://digitalcommons.osgoode.yorku.ca/clpe/93 


\section{OSGOODE}

\section{OSGOODE HALL LAW SCHOOL}

Comparative Research in Law \& Political Economy

RESEARCH PAPER SERIES

Research Paper No. 26/2010

Constitutionalizing the Right of Workers to Organize, Bargain and Strike: The Sight of One Shoulder Shrugging

Harry Arthurs

Editors:

Peer Zumbansen (Osgoode Hall Law School, Toronto, Director, Comparative Research in Law and Political Economy)

John W. Cioffi (University of California at Riverside)

Lisa Philipps (Osgoode Hall Law School, Associate Dean Research)

Nassim Nasser (Osgoode Hall Law School, Toronto,

Production Editor)

Comparative Research in Law \& Political Economy

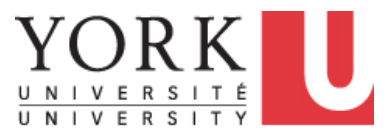


CLPE Research Paper 26/2010

Vol. 06 No. 6 (2010)

Harry Arthurs

\title{
Constitutionalizing the Right of Workers to Organize, Bargain and Strike: The Sight of One Shoulder Shrugging
}

\begin{abstract}
The Supreme Court of Canada may well conclude in Fraser that the Canadian Charter of Rights and Freedoms confers upon agricultural workers the full panoply of bargaining rights provided under contemporary Canadian collective bargaining legislation, from the right to be represented exclusively by the bargaining agent chosen by the majority, to the right to engage their employer in good faith negotiations, to the right to strike. If the Court does so, its decision will be greeted with delight by progressive legal scholars, proponents of countervailing power as a strategy of labour market regulation, and true believers in the potential of constitutional and international rights discourse to transform political economy and social relations. There will be congratulations all 'round: to the skilled advocates who will have achieved a famous victory against long odds; to the imaginative academics who will have erected the conceptual scaffolding on which counsel's arguments will have been constructed; and not least, to the judges who will have finally liberated themselves from the tyranny of precedent and sloughed off 200 years of curial antipathy to workers and their interests.
\end{abstract}

Of course, not everyone will be delighted. Dour devotees of legal logic and historical accuracy are likely to grimace or roll their eyes; neo-liberals who favour unregulated labour markets and managerial unilateralism will cry havoc; and sceptics who question the capacity of courts to bring about deep and lasting change, and the wisdom of asking them to do so, will simply shrug. I consider myself to be a progressive scholar who recalls the bygone era of collective bargaining with great nostalgia; I admire skilled lawyers and free-thinking judges and have built the odd conceptual scaffold for both in my time; and I retain an atavistic attachment to logic and historical accuracy. But because most of all I am a sceptic, I will shrug.

Of course, I will shrug with one shoulder only. Clearly, the Agricultural Employees Protection Act was a cynical attempt to perpetuate the unjustified exclusion of workers on farms and in food processing plants from the regime of collective bargaining. Clearly these workers should have the same rights to organize, bargain and strike as workers in auto plants and banks-however modest the value of those rights may turn out to be in practice. Consequently, if the Supreme Court decides in their favour, one shoulder will remain firmly in place; but the other will shrug. 
Keywords: Fraser, Canadian Charter of Rights and Freedoms, agricultural workers, bargaining rights, Canadian collective bargaining legislation

JEL Classification: J49, J19, K31

UT constrike symp09 final (2010) CJELL [forthcoming]

Harry Arthurs

University Professor Emeritus and

President Emeritus, York University. 


\title{
Constitutionalizing the Right of Workers to Organize, Bargain and Strike: The Sight of One Shoulder Shrugging
}

\author{
Harry Arthurs*
}

\section{INTRODUCTION}

The Supreme Court of Canada may well conclude in Fraser ${ }^{1}$ that the Canadian Charter of Rights and Freedoms ${ }^{2}$ confers upon agricultural workers the full panoply of bargaining rights provided under contemporary Canadian collective bargaining legislation, from the right to be represented exclusively by the bargaining agent chosen by the majority, to the right to engage their employer in good faith negotiations, to the right to strike. If the Court does so, its decision will be greeted with delight by progressive legal scholars, proponents of countervailing power as a strategy of labour market regulation, and true believers in the potential of constitutional and international rights discourse to transform political economy and social relations. There will be congratulations all 'round: to the skilled advocates who will have achieved a famous victory against long odds; to the imaginative academics who will have erected the conceptual scaffolding on which counsel's arguments will have been constructed; and not least, to the judges who will have finally liberated themselves from the tyranny of precedent and sloughed off 200 years of curial antipathy to workers and their interests.

Of course, not everyone will be delighted. Dour devotees of legal logic and historical accuracy are likely to grimace or roll their eyes; ${ }^{3}$ neo-liberals who favour unregulated labour markets and managerial unilateralism will cry havoc; and sceptics who question the capacity of courts to bring about deep and lasting change, and the wisdom of asking them to do so, will simply shrug. I consider myself to be a progressive scholar who recalls the bygone era of collective bargaining with great nostalgia; I admire skilled lawyers and free-thinking judges and have built

\footnotetext{
* University Professor Emeritus and President Emeritus, York University. I am grateful for the research assistance of Danielle Bisnar, and for the helpful comments of participants at the symposium on the Constitutionalization of the Right to Strike, University of Toronto, December 5, 2009.

${ }^{1}$ Fraser v. Ontario (Attorney General) (2008) 301 D.L.R. (4th) 335; leave to appeal granted by the Supreme Court of Canada in Ontario (Attorney General) v. Fraser [2009] S.C.C.A. No. 9

${ }^{2}$ The Charter of Rights and Freedoms, Part I of the Constitution Act, 1982, being Sch. B to the Canada Act 1982 ((U.K.), c. 11 ("the Charter").

${ }^{3}$ See e.g. E. Tucker, "The Constitutional Right to Bargain Collectively: The Ironies of Labour History in the Supreme Court of Canada" (2008) 61 Labour/Le Travail 151; B Langille, "The Freedom of Association Mess: How We Got into It and How We Can Get Out of It" (2009) 54 McGill L.J. 177.
} 
the odd conceptual scaffold for both in my time; and I retain an atavistic attachment to logic and historical accuracy. But because most of all I am a sceptic, I will shrug.

Of course, I will shrug with one shoulder only. Clearly, the Agricultural Employees Protection Act ${ }^{4}$ was a cynical attempt to perpetuate the unjustified exclusion of workers on farms and in food processing plants from the regime of collective bargaining. Clearly these workers should have the same rights to organize, bargain and strike as workers in auto plants and banks-however modest the value of those rights may turn out to be in practice. Consequently, if the Supreme Court decides in their favour, one shoulder will remain firmly in place; but the other will shrug.

Let me explain why.

\section{THE INEFFICACY OF CONSTITUTIONAL LITIGATION}

In a recent co-authored article, "Does the Charter Matter?", 5 attempted to gather all available social and economic data that might help to determine whether since 1982 Canada had changed in the direction the Charter sought to promote. Our methodology was far from perfect; but as no one has so far challenged it or proposed a better one, I stand by our conclusions: despite the profound changes it has brought about in legal theory, doctrine, practice and institutions, the Charter has made little actual difference in our social, economic and political life. Some things have got better; some have got worse; but mostly, they have remained about the same. Moreover, when they have got better - for gays and lesbians for example - it is an open question whether the Charter is the cause or whether judicial rulings in these cases are a consequence of widespread changes in social attitudes that produced equally positive outcomes in countries with no Charter equivalent. And where things have got worse-as in the criminal justice system-one must similarly ask about cause and effect. Has the Charter made things worse, by stirring up police militancy and populist outrage, much as the school desegregation decisions did in the United States? Or would the trend towards strong-arm policing and punitive sentencing have been even worse absent the Charter?

The tentative conclusion of our article - that the Charter does not matter very much represents a hypothesis that can be tested in the following thought experiment. Imagine that ten or twenty years have elapsed since Pepsi-Cola ${ }^{6}$ and Dunmore ${ }^{7}$ and $B C$ Health Services ${ }^{8}$ and Fraser: ${ }^{9}$ Will we likely find a higher proportion of union members in the workforce? Greater

\footnotetext{
${ }^{4}$ S.O. 2002 c. 16.

${ }^{5} \mathrm{H}$. Arthurs \& B. Arnold, “Does the CharterCharter Matter?” (2005) 11 Rev of Constitutional Studies 37.

${ }^{6}$ R.W.D.S.U., Local 558 v Pepsi-Cola Canada Beverages (West) Ltd. [2002] 1 S.C.R. 156 ("Pepsi-Cola")

${ }^{7}$ Dunmore v Ontario (AG) [2001] 3 S.C.R. 1016.

${ }^{8}$ Health Services and Support - Facilities Subsector Bargaining Assn. v British Columbia [2007] 2 S.C.R. 391 ("B.C. Health")

${ }^{9}$ Supra note 1.
} 
union militancy and greater public support for collective bargaining? Improved wages and working conditions? Enhanced job security and a more effective voice for workers in corporate governance? Easier access to labour markets for those who have been excluded from work, and more generous provision for those who confront redundancy or retirement?

The answer to all of these questions, I predict, is likely to be no. Moreover, to the extent that the answer is yes, improvements in the situation of workers are likely to be attributable not to Charter decisions but to other causes, such as a reaction to growing income inequality and recurring and deepening economic crises. Indeed, it is very pertinent - or perhaps impertinent - to note that the improvements in labour's legal fortunes under the Charter over the past decade have coincided with a steep decline in union membership and bargaining power, in workers' job security and real incomes, in the effectiveness of systems of labour market regulation and social protection, and in labour's political influence and cultural salience.

Why is labour's lot unlikely to improve regardless of what the Supreme Court has to say about workers' Charter rights? Here, in abbreviated form, are some possible answers: neo-liberalism; globalization and a new international division of labour; Canada's integration into a USdominated economic space; changes in technology; changes in human resource management strategies; outsourcing and off shoring; demographic change and enhanced diversity in the workforce; the end of internal labour markets; the rise of non-standard and precarious employment; the business community's insurgency against market regulation and the taxpayer revolt against the welfare state. All of these have contributed to the erosion of labour's identity and solidarity, to the unravelling of labour's postwar industrial and political strategies, and to the diminished coverage and efficacy of our collective bargaining system and social legislation.

If, as I will next argue, "labour's" collective identity and solidarity are indeed dissolving; if "labour" as a class or workplace collectivity is no longer capable of effective concerted action; if many prospective targets of such action are no longer within reach of Canadian law; if traditional labour objectives like job security and pensions can no longer be achieved by winning concessions from individual employers, the Supreme Court's recent guarantees of labour's right to organize, bargain, picket and (perhaps) strike will have arrived too late to make much of a difference.

But then, as our study suggests, the difference made by Supreme Court decisions - and by the Charter itself - may always have been over-estimated. Social and economic relations including employment relations - are largely determined not by the formal, juridical constitution but by what I have called the "real constitution"10 - the steep gradient of wealth and power that determines so much in our society. People who have more wealth and power are likely to enjoy better health, housing, education and careers than those who have less. They

${ }^{10} \mathrm{H}$. Arthurs, "Labour and the 'Real' Constitution" (2007) 48 Cahiers du droit 43. 
are also more likely to participate in politics and civic life, and to receive respectful treatment from public officials and the police. And finally, they are more likely to know their rights and to possess the psychic and financial resources needed to vindicate them. ${ }^{11}$ Nonetheless, the Court has so far declined to recognize poor people or workers as "analogous groups" whose members are entitled to economic equality with their more affluent fellow citizens under section $15{ }^{12}$ Nor, if the Court sought to expand the reach of section 15 in this way, is it possible to imagine how it could achieve its goals without engaging in a far-reaching redistribution of wealth for which it lacks both a mandate and institutional competence.

\section{The ROLE OF CONSTItUTIONALIZATION IN REDUCING THE AUTONOMY AND EFFECTIVENESS OF LABOUR LAW}

The historic tendency of labour law had, until lately, been toward autonomy and away from alignment with the "regular" legal system. ${ }^{13}$ This tendency represented not just a reaction to the observable fact that many individual judges were hostile to the interests of workers. Rather, it was driven by two evidence-based concerns: that the values and doctrines of the regular legal system assumed and reinforced a paradigm of social relations in which workers occupied a subordinate rank; and that "ordinary" legal processes and institutions were incapable of comprehending the meaning or of responding to the dynamic of labour relations.

Labour law's historic autonomy project was in many ways successful. The substantive law of employment relations was increasingly codified on the basis of a new and different paradigm of workers as "citizens at work" (not new enough or different enough, some would argue). And this new and distinctive labour law was increasingly administered by specialized labour tribunals, with some degree of expertise in industrial relations, and with procedures and powers that permitted timely and efficacious responses to the power-sensitive and fast-moving world of industrial relations. But the courts have always resisted labour law's autonomy

\footnotetext{
${ }^{11}$ I have developed these ideas in several articles: "Does the Charter Matter?" supra note 4 ; "Labour and the Real Constitution" supra note 9; and "Constitutionalism - An Idea Whose Time Has Come ... and Gone?" (2008) 75:3 Amicus Curiae 3.

${ }^{12}$ Section 15(1): "Every individual is equal before and under the law and has the right to the equal protection and equal benefit of the law without discrimination and, in particular, without discrimination based on race, national or ethnic origin, colour, religion, sex, age or mental or physical disability." The Supreme Court's unwillingness to consider workers or poor people as an "analogous" group worthy of Charter protection confirms (as does everyday observation) that the real constitution trumps the Charter.See e.g. B.C. Health supra note 7 at para. 166; Dunmore supra note 6; Gosselin v Quebec (Attorney General) [2002] 4 S.C.R. 429; Boulter v Nova Scotia Power [2009] NSCA 17 (leave to appeal denied, at http://scc.lexum.umontreal. ca/en/ news release/2009/09-0910.3a/09-09-10.3a.html (last visited September 23, 2009) and more generally S. Boyd, G. Brodsky and S. Day (eds), Poverty: Rights, Citizenship, Legal Activism (Vancouver: UBC Press, 2007).

${ }^{13}$ I have traced this tendency in H. Arthurs, "Developing Industrial Citizenship: A Challenge for Canada's Second Century" (1967) 45 Can. Bar R. 786; "Understanding Labour Law: The Debate Over "Industrial Pluralism" (1985) 38 Curr. Leg. Prob. 83; and "Without the Law": Administrative Justice and Legal Pluralism in Nineteenth Century England (Toronto: Univ. of Toronto Press 1985).
} 
projectand, to some extent, legislatures have as well. A partial list of examples includes: the insistence that cross-examination be permitted in certification proceedings as in adversarystyle criminal and civil trials; ${ }^{14}$ the refusal to acknowledge that arbitrators possess inherent procedural $^{15}$ or remedial ${ }^{16}$ powers; the resistance to replacing the common law industrial torts with statutory rules for waging conflict; ${ }^{17}$ the grudging curial deference accorded to interpretations of labour or general law by labour boards and arbitrators; ${ }^{18}$ the entrenchment of non-constitutional judicial review; ${ }^{19}$ and of course the Charter's suffocating embrace of labour tribunals. ${ }^{20}$

However, despite these - and other - object lessons in the dangers of entanglement in the general law, some former supporters and beneficiaries of labour law's autonomy project have been tempted by the current run of pro-worker Charter decisions to abandon it . I can understand the temptation: labour statutes, tribunals and ministries are not what they used to be. In some cases, they have been actively mobilized to advance the cause of neo-liberalism; in others they have been allowed to slide into obsolescence for want of legislative or administrative modernization; in still others they have been incapacitated by being denied an adequate cadre of committed and knowledgeable personnel. Nonetheless, the present shortcomings of the labour law system will not be remedied by its reincorporation into the general legal system, especially if this is to be accomplished by judges responding ad hoc, and on the basis of broad principles, to the specific conflicts they are asked to adjudicate.

Courts, I would argue, are less well situated than industrial relations experts to design collective bargaining systems. At the very least, the two groups operate on very different assumptions. Courts believe in the power of normativity to transform reality; industrial relations experts believe that economic and social power in reality shapes legal norms. Courts believe in the

${ }^{14}$ In re Ontario Labour Relations Board, [1953] 2 S.C.R. 18.

${ }^{15}$ Union Carbide Canada Ltd. v. Weiler et al., [1968] S.C.R. 966.

${ }^{16}$ Port Arthur Shipbuilding Co. v. Arthurs et al., [1969] S.C.R. 85.

${ }^{17}$ For an early and persuasive statement of the case for displacing common law doctrine and remedies relating to industrial conflict with statutory norms and remedies, see Report of the Task Force on Labour Relations (H.D. Woods, Chair) (Ottawa: Queens Printer, 1968) at 177-187.For an account of a youth misspent in a vain attempt to promote this idea see H. Arthurs "“Woe unto You, Judges: or How Reading Frankfurter and Greene 'The Labor Injunction' Ruined Me as a Labour Lawyer and Made Me as an Academic" (2002) 29 Journal of Law and Society 657.

${ }^{18}$ For the most recent iteration of this debate see New Brunswick (Board of Management) v. Dunsmuir 2008 SCC 9.

${ }^{19}$ Crevier v Québec (Attorney General) [1981] 2 S.C.R. 220.

${ }^{20}$ Weber v Ontario Hydro, [1995] 2 SCR 929. 
permanence and solidity of law; experts are all too aware of its transience and fragility. Courts believe in the generality of law: everyone is bound by the constitution; everyone should enjoy the protections of the Charter. Experts tend to believe in law's specificity: different circumstances and situations call for different treatment; if statutes cannot be drafted $a b$ initio to ensure difference, difference can and should be accommodated by delegating regulationmaking powers or adjudicative discretion to an expert administrative body. ${ }^{21}$

Nonetheless, a court-managed exercise in the design of an industrial relations regime for agricultural workers will likely be launched by the decision of the Ontario Court of Appeal in Fraser, the Supreme Court's response to that decision, and the ensuing "dialogue" (if any) ${ }^{22}$ between that Court and the Ontario legislature.. By extension, the design ultimately deemed by the Court to pass constitutional muster will almost certainly determine the options available to other groups disfavoured by current arrangements. And ultimately, the tail will wag the dog: Charter constraints adopted to protect marginalized groups of workers will determine the range of options available for the future overall redesign of the industrial relations system.

Consider, therefore, the range of legislative responses that the Supreme Court might accept as meeting the "freedom of association" test laid down in BC Health and (one anticipates) reaffirmed in Fraser.

- The Court might require that the legislature treat agricultural workers in precisely the same way as all other "employees" ? ${ }^{23}$ It might therefore decide that they have the same right as other workers to strike after selecting a bargaining agent, securing certification, engaging in good faith negotiations, and exhausting the conciliation procedures laid down in the Labour Relations $\mathrm{Act}^{24}$. But what if such rights avail them naught? What if those procedures are so attenuated that seasonal workers are unable to exercise them? Or if unskilled agricultural workers are so easy to replace that they cannot mount an effective strike? Or if produce can easily be imported to replace crops grown locally by striking workers? Could a sympathetic legislature decide, for example, to replace the right to strike with compulsory arbitration? Or to substitute legislated labour standards for negotiated terms and conditions of employment?

- Or the Court might allow the legislature to create a separate but equal collective bargaining regime for agricultural workers, as it has for civil servants ${ }^{25}$ and teachers, ${ }^{26}$ and for public

\footnotetext{
${ }^{21}$ For the fullest adumbration of this idea in the Canadian context, see P. Weiler, Reconcilable Differences: New Directions in Canadian Labour Law (Carswell, Toronto, 1980).

${ }^{22}$ P. Hogg \& A.Bushell, "The Charter Dialogue Between Courts and Legislatures" (1997) 35 OHL 75 and P. Hogg, A. Bushell Thornton \& W. Wright, "Charter Dialogue Revisited" (2007) 45 OHL 1; but see contra G. Huscroft, "Constitutionalism from the Top Down" (2007) 45 OHL 91 and A. Petter "Taking Dialogue Much Too Seriously" (2007) 45 OHL 147.

${ }^{23}$ This is the strong implication of Chief Justice Winkler's judgment.

${ }^{24}$ Ontario Labour Relations Act, 1995, S.O. Chapter 1, Schedule A

${ }^{25}$ Crown Employees Collective Bargaining Act, S.O. 1993 c 38 as amended.
} 
safety, ${ }^{27}$ college $^{28}$ construction ${ }^{29}$ and hospital workers? ${ }^{30}$ However, no one can predict what degree of deference the Court will accord to a legislative determination about what is "equal" and what needs to be "separate". What one can predict is that with the best of intentions, the Supreme Court is unlikely to appreciate the subtleties of labour-management relations in agriculture, and the rules, processes and institutions appropriate to regulate them.l offer as Exhibit A the Court's attempt in Weber to protect and expand the jurisdiction of labour arbitration boards, thereby rendering them virtually incapable of performing their core functions. ${ }^{31}$ Exhibits $B$ to $Z$ are available on request.

- Or the Court might be minimally prescriptive. It might simply say, as it did in Pepsi-Cola with regard to picketing, ${ }^{32}$ that agricultural workers are free to strike at any time -- so long as they do not commit a crime or tort (or, for that matter, breach a statute or a contract). Anyone familiar with the common law or criminal law of picketing (other than judges of the Supreme Court) would recognize how drastic a restriction lies concealed within this apparently modest caveat. ${ }^{33}$ Postmodernism has been described as "private jokes in public places". The same is likely to be said of Pepsi-Cola, and perhaps of B.C. Health and Fraser once their post-history unfolds.

Each of these three possible scenarios for post-Fraser legislation suggests that court-mandated, Charter-driven solutions to the plight of agricultural workers may well achieve too much or too little. This is not to assert that statutory schemes designed by experts and enacted by legislators - also known as politicians -inevitably respect the norms of sound industrial relations. The statutes impugned in BC Health, Dunmore and Fraser are evidence to the

\footnotetext{
${ }^{26}$ See Police Services Act, S.O. Part VIII; Fire Protection and Prevention Act, S.O. 1997 c. 4. Part IX.

${ }^{27}$ Education Act R.S.O. c. E-2 part X.1.

${ }^{28}$ Colleges Collective Bargaining Act 2008 S.O. c. 15.

${ }^{29}$ Labour Relations Act, supra note 24 , ss. $126-168$ as amended.

${ }^{30}$ Hospital Labour Disputes Arbitration Act, R.S.O. 1990 c. H.14.

${ }^{31}$ Supra note 20. See e.g. M. Picher, "Defining the Scope of Arbitration: The Impact of Weber - An Arbitrator's Perspective" (1999-2000) Lab. Arb. Y. B. 99; H. Arthurs, "The New Economy and the New Legality: Industrial Citizenship and the Future of Labour Arbitration," (2000) 7 CLELJ 45; C. Mummé, "Labour Arbitration as Translation: The Transformation of Canadian Labour Arbitration in the Twentieth Century from a SemiAutonomous Institution of the Shop to an Institution of the State" (January 1, 2008). Available at SSRN: http://ssrn.com/ abstract=1485682

${ }^{32}$ Supra note 6 at para. 68.

${ }^{33}$ See e.g. H. Arthurs, "Tort Liability for Strikes in Canada: Some Problems of Judicial Workmanship" (1960) 38 Can. Bar R. 346; I. Christie, The Liability of Strikers in the Law of Tort (Kingston: Industrial Relations Centre, 1967); S. Tacon, Tort Liability in a Collective Bargaining Regime (Toronto: Butterworths, 1980).
} 
contrary.I do argue, however, that to use the Charter as a template for the design of industrial relations systems is to increase the risk that in the long term, the approach of courts will prevail over that of experts. This in turn enhances the likelihood that legislatures will arrive at dysfunctional or at least sub-optimal solutions.

Worse yet: even if Charter-driven solutions work well at the time they are adopted, their constitutional character virtually ensures that we will have to live with them long after they have ceased to work well. Will we, for example, always accept that a conflict-based system which entrenches the right to strike is intrinsically fairer for workers than a principles-based system in which wages and working conditions are adjudicated? Or that a system in which important benefits are delivered to workers through collective bargaining is necessarily more efficient than one in which such benefits are delivered by the state? Or that a system which keeps workers and employers at arm's length is preferable to one where workers share ownership and control of the enterprise? Or that a system which awards majority unions exclusive bargaining rights is more likely to promote union membership and strength than one where minority unionism is permitted $?^{34} \mathrm{I}$ am not advocating that we abandon our present system in favour of any of these alternatives; but I am arguing that we ought to be as wary of constitutionalizing the modalities of our present system of collective bargaining as (in hindsight) we should have been in constitutionalizing denominational schools in Newfoundland or the ferry to Prince Edward Island.

\section{WHAT DOES CONSTITUTIONALIZATION SIGNIFY?}

What remains, of course, is to clarify what we mean by "constitutionalization". ${ }^{35}$

Much of my analysis has proceeded on the basis that constitutionalization involves embedding in our basic law a legally enforceable right from which no legislature or court can derogate.Used in this sense, constitutionalization requires that we determine whether an activity, such as a strike, is protected or guaranteed by specific constitutional language.Thus, the Court of Appeal in Fraser held that the right to bargain collectively, as understood in our present system, is guaranteed by section 2(d) of the Charter as the exercise of "freedom of association. ${ }^{36}$ Brian Langille has argued to the contrary, that the right of agricultural workers to be treated like other workers should be guaranteed under section 15 of the Charter as an equality right. ${ }^{37}$ And conceivably - nothing is inconceivable after Chaoulli $i^{38}-$ since collective

${ }^{34}$ On this point see R. Adams, Industrial Relations under Liberal Democracy: North America in Comparative Perspective (USC Press 1995); and R. Adams, Labour Left Out: Canada's Failure to Protect and Promote Collective Bargaining as a Human Right (Ottawa: Centre for Policy Alternatives, 2006). However Adams' argument against majoritarian unionism was specifically rejected by Chief Justice Winkler in Fraser, supra note ?? at paras. 86-93 .

${ }^{35}$ For a taxonomy see H. Arthurs, "The Constitutionalization of Employment Relations: Pernicious Problems, Multiple Models" (2010) [forthcoming].

${ }^{36}$ Supra note 1 at para. 101.

${ }^{37}$ Supra note 2. 
bargaining, and ultimately strikes, may in given circumstances be the only means by whichagricultural workers can defend their "liberty" or the "security of [their] person", their right to strike should be guaranteed under section 7 of the Charter. ${ }^{39}$

I will leave that debate to others. Instead I want to note that an older and different meaning of "constitution" is rooted in British public law and therefore, because of its "constitution similar in principle" preamble, in our Constitution Act 1867 as well. In this usage, the word "constitution" is less prescriptive than descriptive: it identifies, explains and gives legitimacy to the way in which things are presently constituted, without necessarily creating enforceable rights. This may explain Chief Justice Winkler's reasoning in Fraser to the effect that since "labour relations policy in Canada has long recognized" the desirability of our present collective bargaining system, the main features of that system are entitled to "constitutional" protection. ${ }^{40} \mathrm{~A}$ similar usage of "constitution" has a very long history in industrial relations discourse. ${ }^{41}$ It survives down to the present in union claims that "custom" or "past practice" may require that employers respect certain workplace norms even though they are not based on the specific terms of a collective agreement, and in the assertion by employers of their "inherent management right" to retain unilateral control of all aspects of decision-making in the enterprise other than those explicitly agreed to be taken jointly with the union.

However, such arguments are not without their difficulties. For example, if the longevity of a system automatically entitles it to constitutional protection, how will old systems ever be superseded by new ones? Nonetheless, the description of a privileged and presumptively entrenched status quo as "constitutional" does serve one useful purpose. It forces us to look carefully at "how things are constituted", and to scrutinize proposed changes with equal care.

Thus the real importance of attributing constitutional significance to workers' rights is not that they thereby become enforceable or, as I earlier suggested, that if they are enforced in individual cases, significant and positive social and economic changes necessarily ensue in the industrial relations system. Rather, the claim that certain rights enjoy constitutional status forces us to confront the conflicts inherent in our political economy and social order, in the

\footnotetext{
${ }^{38}$ Chaoulli v Québec (Attorney General) [2005] SCR 791.

${ }^{39}$ Section 7 reads as follows: "Everyone has the right to life, liberty and security of the person and the right not to be deprived thereof except in accordance with the principles of fundamental justice."

${ }^{40}$ Fraser supra note 1 at para. 87-88.

${ }^{41}$ A very early example of a so-called "ancient constitution" governing employment relations involved the Crowley Iron Works, an $18^{\text {th }}$ century proto-capitalist enterprise: see A. Harding, A Social History of English Law (Gloucester, Mass.: Peter Smith, 1966) at 327 A partial text of the Crowley "constitution" is found in M.W. Flinn (ed), The Law Book of the Crowley Ironworks (Durham: Surtees Society, 1952).
} 
conventions of employment relations, and in the interpretation of our basic law by our highest Court.

The characterization of "labour" in Canadian constitutional law is a case in point. Legislative authority over labour issues was originally assigned to the provinces precisely because such issues were perceived to be matters of "civil [i.e. contractual] rights", and of a "merely local and private nature" ${ }^{\prime 42}$ under s. 92 of the Constitution Act. By contrast, in contemporary judicial rhetoric, labour legislation, common law doctrines bearing on workers' rights, and the actions of public employers are subject to Charter standards precisely because they implicate issues of self-fulfillment, personal identity and dignity, the well-being of individuals and families, freedom, justice and power. ${ }^{43}$ These characterizations are fundamentally at odds with each other. The former assigns the employment relation to the domain of private ordering and regulation (if any) on a local level; the latter contemplates, even invites, active state intervention with a view to ensuring decent working conditions and equal employment rights for all Canadians.

A similar shift in the characterization of workers' rights and interests is also manifest in the Supreme Court's changing attitude to international labour standards. Such standards were once adjudged so remote from "local" wage bargains made "in the province" and under its legislative authority that even ratification of those standards by the federal government gave them no legal effect. ${ }^{44}$ Now, it appears, they are so fundamental to our jurisprudence that even without a province's accession or enactment they can pour new meaning into the Charter, de-legitimate its legislation and rewrite its common law. ${ }^{45}$ Of course this new (and possibly exaggerated) deference to international norms may be a mere rhetorical device used by judges to reinforce their preferred outcome in a particular case. On the other hand, it may constitute belated acknowledgement by courts of what the rest of us have known for some time: that employment relationships are now constituted by global and national labour markets; that a decent system of industrial relations is a prerequisite for Canada's civil peace, social justice and economic development; and that the time has come to characterize labour issues as public and national or global, not contractual, private and local.

Such a reconceptualization of "labour" might have far-reaching consequences. It might permit the regulation of industrial relations across Canada's nationwide labour market, ${ }^{46}$

\footnotetext{
${ }^{42}$ Toronto Electric Commissioners v Snider [1925] A.C. 394.

${ }^{43}$ A stirring early example was the dissenting judgment of Dickson CJC and Wilson J in Reference re Public Service Employees Relations Act (Alberta) [1987] 1 S.C.R. 313.

${ }^{44}$ Reference re: Weekly Rest in Industrial Undertakings Act (Can.) [1937] A.C. 326 (Labour Conventions case).

${ }^{45}$ Dunmore supra note 6 ; B.C. Health supra note 7;Pepsi Cola supra note 5; and see G. England, "The Impact of the Charter on Individual Employment Law in Canada: Rewriting an Old Story" (2006) 13 CLELJ 1.

${ }^{46}$ The existence of a nationwide labour market is guaranteed under the Charter by the mobility rights provision (section 6(2)) and underpinned by the commitment in principle to equalization of provincial revenues and the elimination of regional disparities of access to public goods (section 36).
} 
unconstrained by jurisdictional boundaries, and might facilitate linkages between labour market issues and other policy domains It might force us to acknowledge, for example, that minimum wage statutes do not merely set out the non-derogable terms of the employment bargain; they help to reduce the incidence and eliminate the effects of poverty.- It might lead us to accept that pension laws do not merely regulate arrangements under which wages can be deferred and tax-sheltered until retirement; they define the future life prospects of a rapidly increasing segment of Canada's population. And it might prompt us to recollect that collective bargaining legislation does not merely establish countervailing economic power in individual workplaces; it enables the formation of a worker-based political movement with the capacity to influence debates on public policies ranging from health care to immigration, from free trade to taxation. In short, reconceptualization of labour's constitutional significance might open our eyes to new policy approaches, engage new actors, remind us of normative regimes whose influence we have not previously suspected, and make evident new connections among ideas and events, interests and institutions.

Reconceptualization "might" do all of these things, but so far it has done none of them. The reason is that Charter litigation is self-regarding; it focuses on changes read into the formal, juridical constitution by judges rather than changes in the "real" constitution wrought by the contending forces of political economy; and it assumes but fails to explore - let alone empirically demonstrate - any connection between these two constitutions. My oneshouldered shrug, then, is meant to provoke those concerned about labour's plight to acknowledge more explicitly the primacy of social and political over legal mobilization, and to engage more extensively in scholarship that takes them beyond the boundaries of rights discourse. 